\title{
Multinational Enterprises and the 'One Belt, One Road' Initiative: Sustainable Development and Innovation in a Post- Crisis Global Environment
}

\author{
ULRIKE SOLMECKE
}

\begin{abstract}
By initiating the development of a gigantic international trade network across Asia, Europe and Africa, with several trade corridors that will span around 60 countries, China intends to stimulate substantial economic growth. Already in the first phase, focused on building an adequate infrastructure, multinational enterprises will play a vital role in developing the so-called New Silk Road or the 'One Belt, One Road' initiative. This article inquires into the environmental impacts that a venture of this magnitude will entail and discusses the potential of the available voluntary and mandatory governance instruments to lead the key economic actors to take sustainability criteria into account.
\end{abstract}

Keywords: One Belt, One Road; multinational enterprises; environmental impacts; sustainability innovations; governance instruments

\section{Introduction}

The New Silk Road or the 'One Belt, One Road' (OBOR) initiative aims at nothing less than creating a comprehensive trading network across three continents - Asia, Europe and Africa - thereby integrating around 60 countries with a total of about 63 per cent of the global population, presently generating 29 per cent of worldwide GDP (Wang 2014). The concept of the '21st Century Maritime Silk Road' as a means to intensify China's maritime cooperation with Asian countries and to develop new trade routes via Africa to Europe was introduced in October 2013 by the Chinese president in a speech at the Indonesian parliament. The maritime road is planned to include two main routes: 1) From China through the South China Sea to the Indian Ocean and from there to Europe and, 2) from China via the South China Sea to the South Pacific (Eyler 2015a; ${ }^{1}$ Leung 2015; ${ }^{2}$ Maritime Insight 2015). ${ }^{3}$ During another speech, just one 
month earlier at the Nazarbayev University in Khazakstan, Xi Jinping had already revealed his vision to build a 'Silk Road Economic Belt' between Europe and China - a land route that would not only connect two of the world's most vibrant economic hubs but also generate economic impetus and create new markets in the regions between them.

Although sea transport will probably remain the dominant form of freight transport in the foreseeable future, the concept of a land bridge connecting so many markets by approximately $12,000 \mathrm{~km}$ of track offers a wide range of new economic incentives. Furthermore, transporting the goods by rail provides a much faster connection between Europe and China. While a container ship needs 30 to 40 days, goods delivered by train would reach their destination in only 14 to 18 days (Arduino 2014).

The railway network will bring together Asian, European and African countries via three main routes, each with China as the starting point: (1) to Central Asia, Russia and Europe (the Baltic), (2) to the Persian Gulf and the Mediterranean Sea through Central and West Asia and (3) to Southeast Asia, South Asia and the Indian Ocean. The main lines that have already been launched connect Chongqing and Duisburg (Germany) since 2011; Wuhan to Pardubice (Czech Republic) since 2012; Chengdu to Lodz (Poland) since 2013; Zhengzhou to Hamburg (Germany) since 2013; Yiwu to Madrid (Spain) since 2014; and Wuhan to Hamburg (Germany) since 2015 (Arduino 2014; Leung 2015; Suárez 2014). ${ }^{4}$

Similar to the maritime network, which builds on an already existing network, the idea of a Eurasian railway network is not entirely new. As stated above, some of the main lines have already been in use for some time. The connection between Yiwu and Madrid, for instance, uses, among others, parts of the Trans-Siberian Railroad as well as established railway links passing through Germany and France (Suárez 2014). However, up until now trains primarily carried freight from China to Europe and not vice versa.

Nevertheless, the OBOR initiative has gained considerable momentum since the vision was first outlined by Xi Jinping, (NDRC et al. 2015; Wang 2014). Not only do most of the Chinese provinces and municipalities explicitly plan to incorporate the project into their economic planning (Wangyi 2015), ${ }^{5}$ but the initiative also met with an overwhelmingly positive response from the governments of nearly all countries posited to be integrated into the project. China has been able to enter into bilateral agreements with a vast number of individual states throughout Asia and Europe as well as with several trading blocs. The latter includes engagement in the EU investment offensive, launched in 2014 (EU- 
China 2015; Zhao 2015), ${ }^{6}$ a memorandum concerning OBOR with the sixteen central and Eastern Europe (CEE) countries (Xinhua 2015) ${ }^{7}$ and intensified cooperation with the ASEAN via the ASEAN Master Plan for Connectivity (AMPC) (Blanco Pitlo 2015). ${ }^{8}$

The OBOR initiative is funded by a range of financial institutions. These include the US $\$ 40$ billion Silk Road Fund, founded in November 2014; the US $\$ 100$ billion Asian Infrastructure Investment Bank (AIIB), established in June 2015; the US\$100 billion BRICS New Development Bank, founded in July 2014; and US\$50-100 billion coming from the sovereign wealth fund China Investment Corp., which was incorporated in January 2015.

Economic plans of such magnitude cannot be seen in isolation from the vast array of environmental parameters deteriorating worldwide - a process fuelled by a global growth-driven model of development. Against this background, this article looks at the environmental impacts of the OBOR initiative and examines the question of how and to what extent the key economic actors in this initiative are incentivized to adopt a more sustainable behaviour by mandatory and voluntary governance instruments.

\section{The Environmental Importance of the OBOR Initiative}

The recently concluded UN Climate Change Conference in Paris set ambitious goals concerning the direction of development for the next decades. The Paris Agreement, negotiated during the Conference of the Parties of the UNFCCC and adopted by consensus ${ }^{9}$ but not fully ratified, aims at 'holding the increase in the global average temperature to well below $2{ }^{\circ} \mathrm{C}$ above pre-industrial levels and pursuing efforts to limit the temperature increase to $1.5^{\circ} \mathrm{C}$ above pre-industrial levels' (FCCC/CP/2015/L.9/Rev.1: 2). At the same time, the agreement already acknowledges that the currently intended nationally determined contributions (INDCs) are not sufficient to limit greenhouse gas emissions to a level ensuring the achievement of these aims (UNFCCC INDC 2015). ${ }^{10}$ De facto it is assumed that the emissions, based on the INDCs, will exceed the acceptable level by at least 15 gigatonnes in 2030 (FCCC/CP/2015/L.9/Rev.1: 3). In addition, by 2013 experts had already estimated that the time window for temperature stabilization targets below $1.7^{\circ} \mathrm{C}$ would be closed due to prohibitively high economic mitigation challenges and that delaying substantial reductions by another fifteen years would push the 2-degree target out of reach as well 
(Luderer et al. 2013: 6f). As such, the significance of the environmental impacts triggered by the OBOR project - an economic initiative designed to substantially boost economic growth on three continents - should not be underestimated.

The first wave of investments will go towards developing an infrastructure extensive enough to support a trade network of the envisaged dimensions. According to estimates, the investments had already boosted China's GDP by 0.25 per cent in 2015 (Wang 2015b). ${ }^{11}$ The construction and expansion of transportation and logistics facilities are mainly carried out by multinational enterprises ${ }^{12}$ dominating these sectors (Dai 2014). ${ }^{13}$ Accordingly, the overall sustainability balance of the OBOR initiative will be critically dependent on how the companies concerned act with respect to sustainability issues and how efficient incentives prove to be in positively affecting their environmental performance.

The infrastructure-related industry comprises a wide range of different branches, which cannot be analysed within the limited space of this article. However, with regard to the aim of looking into the conditions for a sustainable development of the OBOR project, it seems useful to concentrate on two of the most involved sectors which also rank among those with the highest environmental impact: the transportation sector and the construction industry, with a focus on the cement segment.

Motorized transport is responsible for 23 per cent of global energyrelated $\mathrm{CO} 2$ emissions - with the freight segment alone accounting for 10 per cent (WEC 2011). The cement industry has a share of 6 per cent in worldwide emissions (WBCSD 2012). Apart from this, both sectors contribute substantially to the deterioration of a considerable number of environmental indicators. The extraction of raw materials in cement production, for example, results in soil degradation, as well as in the loss of biodiversity and cultivable or natural areas. The main damages caused by the transport industry range from massive water and air pollution to the impairment of sensitive natural areas. By adding to the overuse of natural resources or sinks both industries thus negatively affect parameters of global environmental change and add to the pressure on planetary boundaries (Rockström et al 2009) even beyond climate effects.

\section{Theoretical and Methodological Framework}

Research on the sustainability-relevant behaviour of industry sectors quickly runs up against limitations when mainstream economic theories - especially neoclassical approaches - are applied. This is because they 
focus primarily on equilibrium conditions. Since the 1980s academics have increasingly turned to alternative economic approaches more suited to describing and analysing transition processes and which allow for a stronger focus on the role of individual actors (Nelson and Winter 1982). Within this context, the willingness of companies to adopt innovations and thus change their environmental behaviour plays a central role. More recent studies on innovations, their diffusion and their relevance for environmentally compatible production processes have found it useful to base their analyses on two interlinked alternative approaches: 1) evolutionary economics, which treats periods of adaption as the normal state along development pathways and; 2) diffusion theory, which aims to explain the development and influencing factors of decision-relevant attitudes and conditions concerning innovations (Rogers 2003). Sustainability innovation is here understood as:

the development and implementation of a technical, organisational, institutional or social problem solution contributing to the preservation of critical natural assets and to economic activities and consumption level which are feasible on a long-term and global basis. (Clausen, Fichter and Winter 2011: 9)

Following the baseline study on diffusion paths by Clausen, Fichter and Winter (2011: 51), this article assumes that a development path is not only affected by endogenous parameters but by various external variables acting as pull and push factors. In this context it concentrates on two of the influence spheres, namely sector-specific and policy-related influences.

Intervention by external actors is divided into regulatory push and pull factors. Regulatory push comes from national and supranational regulations aiming at exnovation, i.e. the avoidance or reduction of environmentally destructive practices. They comprise all process steps from political discussion regarding measures of legal provisions and prohibitions, up to their effective enactment. Regulatory pull can be exerted through incentives for innovations and their diffusion by defining environmental targets, providing subsidies and preferential fiscal treatment, as well as creating a favourable legal framework (Clausen, Fichter and Winter 2011: 86-87).

The OBOR project has ambitious economic goals and it will involve some of the most highly polluting industries. As such, it can be expected that channelling the development in a more sustainable direction will not be easy (Shu 2016) ${ }^{14}$ and will require clear incentives and strong sets of rules. This article will survey the role and potential of voluntary and mandatory governance arrangements in inducing companies to move 
away from unsustainable pathways and adopt more environmentally sound innovations.

\section{The Role of Multinational Enterprises}

The majority of future customers using the new infrastructure envisioned by the OBOR initiative will be manufacturers of consumer goods and trading companies that need freight transport capacities and - to a certain degree - passenger transport facilities as well. The extension of the modal split with the aim to enhance the Eurasian trade network had received an overwhelmingly positive response by European and Asian enterprises alike - thus indicating a huge demand regarding both already existent markets as well as totally new segments like the rail shipment of perishables from the Netherlands to China (Ni 2015). ${ }^{15}$ Not least, Asian e-commerce is growing with amazing speed and it needs additional transport and warehouse facilities (Fung Business 2013; Ding 2010; ${ }^{16}$ The State Council). ${ }^{17}$

A broad spectrum of different multinational transport providers throughout Asia and Europe are responding to this trend by expanding their service across the whole range of transportation modes. Whether new outlets, as well as short and middle distance transportation and logistical support, will attract small and middle-sized companies remains to be seen, though it seems likely. However, in the context of long-distance transportation and complex logistical operations the dominance of Asian and European-based multinational enterprises is already evident. They build on comprehensive know-how and are already successfully engaged in various business segments including, for example, multi-modal transport.

Aside from the transportation sector, the planned trade network involves substantial investments in logistic infrastructure, including the construction or extension of dry ports, ports, airports, train stations, warehouses and road networks, etc. In particular, the emergence of new logistic and trade hubs, like the Chengdu-Chongqing area in China, comes with a huge construction demand (Chengdu Ribao; ${ }^{18}$ Wang 2015a). ${ }^{19}$ In the context of excessive capacities following the overheated development in the Chinese real estate market, the OBOR initiative is at least partially designed as a 'going out' strategy (zou chu $q u)$ for Chinese infrastructure-related companies to meet overcapacity problems(Eyler 2015b; ${ }^{20}$ He 2015; ${ }^{21}$ Zhao and Yang 2015). Thus, the cement industry, supplying one of the most crucial building materials, is 
among the primary beneficiaries of China's OBOR project. China's overcapacity in cement production is enormous. With a capacity utilization of 65 per cent, Chinese cement enterprises, suffering from a dwindling demand, are well below worldwide average. From an economic point of view, China's total production capacity could be curbed by at least one third, which would amount to one eighth of global production (Perilli 2015).

Overcapacities are, however, by no means the sole problem for the Chinese building materials sector. Revenue decline due to overcapacity troubles almost all infrastructure-related industries in China. This applies, for example, to the railway industry (China Daily 2015; Zhao and Yang 2015) and ocean carriers and sea freight forwarders (Wei 2015). ${ }^{22}$ The Chinese aviation market has been one of the fastest growing markets worldwide but the rapid expansion has not been accompanied by appropriate economic success. Some 75 per cent of all Chinese airports run a deficit, and high-speed rail has become an increasingly serious competitor for airlines, especially in relation to flights within China (Solmecke 2014: 285ff).

For European multinationals the OBOR initiative also comes at a time when global demand is slowing (Wei 2015). The Chinese strategy concerning trade corridors through Europe coincided with European Union plans to stimulate the economy, lagging in the wake of the global economic and financial crisis, and to deepen the single market with a new investment plan (European Commission 2015). ${ }^{23}$ Like the OBOR initiative, this investment plan puts a clear focus on the expansion of demand in order to revitalize economic growth (EU 2014). It is intended that these 'flagship initiatives' (EU-China 2015) will be closely coupled in the future. In order to generate and maximize synergies and connectivity, a working group comprising experts from the Chinese Silk Road Fund, the European Commission and the European Investment Bank (EIB) was set up in 2015. It seeks to create concrete opportunities for China to invest in the European investment plan, namely within the context of the OBOR initiative.

Beside economic goals, the OBOR programme and the EU investment strategy, as well as the funding institutions, emphasize environmental soundness and sustainable development as core objectives (AIIB 2015: Chap.1; Michael 2015). ${ }^{24}$ In the context of anthropogenic climate change the importance of low-carbon development is particularly stressed (AIIB 2016a; The State Council 2014b;25 The State Council 2015: 2, 5;26 Xinhua 2014). ${ }^{27}$ Within this nexus of economic and environmental goals 
European and Chinese multinationals are developing their strategies for their Eurasian business activities.

\section{Multinationals and Incentives for Sustainable Development}

The main actors in the OBOR project are well-established companies that are widening and strengthening their business fields. This makes it difficult to create a favourable climate for profound sustainability-relevant changes that would require multinationals to give up well-tested and profitable business practices. Studies on path dependencies (Clausen, Fichter and Winter 2011: 47ff; Lehmann-Waffenschmidt and Reichel 2000) show that development paths are largely dependent on routines. Based on the economic advantages of using established methods, technologies or organisational processes they can result in little willingness to leave routinized pathways and open up for new innovations.

Political instruments aiming to influence the industry's development paths can be found on several levels and the subject of much debate. Political incentives which could have a significant 'push'-effect in the sense of exnovation (David 2014) or that would at least partially reduce the use of transportation means with high emission rates are weak - at the national as well as international levels. Kerosene and marine diesel are not taxed - resulting in, de facto, an indirect subsidization to the detriment of less-polluting transport. Moreover, aviation and shipping are not subject to international regulations. This includes the Paris agreement, which did not produce any reduction obligations for these industries, despite the fact that both air and shipping traffic have huge growth rates, thus aggravating the problem of their already high emissions. Since 1990 CO2 emissions from aviation have increased by 87 per cent and from shipping by 70 per cent (European Federation for Transport \& Environment 2011). ${ }^{28}$ Instead of including these sectors in a regulatory framework, the International Maritime Organization (IMO) and the International Civil Aviation Organization (ICAO), specialized agencies of the United Nations, albeit strongly influenced by the industry, have been entrusted with the formulation of voluntary reduction targets. As these targets are non-binding, the pressure to realize them remains low.

The same holds true for the cement industry. The fact that a single sector is liable for a 6 per cent share of global emissions (WBCSD 2012: 5) is reason enough to be concerned, but cement consumption has also been growing steadily at a rate of approximately 2.5 per cent each year and is 
expected to increase at an even faster rate of up to 4 per cent. During the COP21 in Paris the cement industry committed itself to a 20-25 per cent reduction of $\mathrm{CO} 2$ emissions by 2030 compared to business as usual - a goal which is neither ambitious nor binding (CSI 2015; ${ }^{29} \mathrm{FCCC} / \mathrm{CP} / 2015$ / L.9/Rev.1, 2015).

\section{The Cement Industry}

The national regulatory frameworks setting the rules and determining the scope of action for the sectors discussed are complex. First of all, a wide range of climate-related regulations have been passed by national governments and the EU in recent years. For China, the Energy Development Strategy Action Plan (2014-2020) and the National Climate Change Adaptation Plan (2014-2020), both issued in 2014 by the Chinese government (The State Council 2014a; ${ }^{30} 2014 \mathrm{c}$ ), ${ }^{31}$ affect development opportunities for the industry. The Energy Development Strategy Action Plan foresees a cap set on annual primary energy consumption at 4.8 billion tonnes of the standard coal equivalent until 2020. It aims at the restructuring of the energy mix towards clean energy, ${ }^{32}$ especially at the restriction of coal consumption which is planned to be held below 4.2 billion tonnes until 2020 (Xiang 2014). ${ }^{33}$

In recent years the Chinese authorities have increasingly strictly supervised compliance with national standards concerning emissions. Steel- and iron-processing enterprises as well as cement manufacturers are shut down or severely punished if they do not meet standard requirements or if they use illegal production techniques (NDRC 2014: 5; ${ }^{34}$ NDRC 2015: 4). ${ }^{35}$

Analyses show that the new policy directives are likely to reduce emissions in an effective way, provided that China embarks on a path of slower growth and creates incentives to reduce inefficiencies in resource allocation (Zhang et al 2014: 6). These goals were both articulated in China's Third Plenum (China Daily). ${ }^{36}$ Whether they are put into practice remains to be seen.

Nevertheless, there are some facts limiting the potential success of the regulations. On the one hand, they only affect companies operating in China. As Chinese enterprises are explicitly encouraged to 'go out' (Eyler $2015 b)$, there is a considerable risk that environmental standards are diluted when investments are made in other countries. This is particularly the case in Eastern Europe or South and Central Asia where national environmental regulations, for example concerning pollution restrictions, are relatively weak (McGarrity and Walker 2015; ${ }^{37}$ Rosenthal 2007; ${ }^{38}$ Zhu 
and Hoffman 2015). This is, for example, the case in Tajikistan where the cement industry is currently one of the most booming economic sectors. Although environmental standards exist, their enforcement remains poor so that Chinese cement plants, which have been engaging in the sector very successfully lately, face far weaker regulatory boundaries concerning their energy sources and environmental standards than they would in China (van der Kley 2016). ${ }^{39}$

On the other hand, regulations only impact on a part of $\mathrm{CO} 2$ emission sources. An outstanding example is cement production: Portland cement has become the most common type of cement for all kinds of infrastructure projects since its invention in the first half of the nineteenth century. Approximately 50 per cent of $\mathrm{CO} 2$ emitted in the manufacturing process originates from the chemical reaction that converts limestone to the primary precursor of cement: calcium oxide. Another relevant emission source is the fossil fuel combustion during the manufacturing process because cement is produced at very high temperatures. The remaining emissions come from transport and electricity in roughly equal parts (WBCSD 2012: 4). CO2 restrictions aim at the energy-related process while there is a lack of push factors designed to limit emissions generated during the chemical process.

Although less polluting cement variations have been available for more than two decades, Portland cement still undisputedly dominates the market. While there is no exnovation-push strong enough to support the phasing out of conventional cement production, bureaucratic hurdles concerning standardization and certification prolong the time it takes to bring the new technologies to the market (Rousseau,n.d.) ${ }^{40}$ and make market entry even more difficult. Thus institutional arrangements do not only lack push factors but also hinder the diffusion of innovations. In fact, given the financial and political support concerning growth strategies of companies in the context of the OBOR project and the tight timeframe to start infrastructure projects, innovation-orientation could even hamper competitiveness. In combination with financial incentives provided by the project-funding institutions, institutional arrangements therefore act as binding forces that prevent companies from leaving conventional pathways.

\section{Transport and Logistics}

Financial mechanisms work similarly in the transportation sector. In fact, the forced development of a railway network is comparatively favourable for the environment as it is the transport mode for cargo 
with the smallest ecological footprint - the extent of the ecological advantages obviously depend on the type of energy supply. Average distance CO2-emissions (per metric ton of freight and per kilometre) of $62 \mathrm{~g}$ for road transport and $600 \mathrm{~g}$ for air transport on the one hand and of $30 \mathrm{~g}$ for rail transport on the other show a clear advantage in the latter. Although seafreight is - with 10g CO2 per tonne-km (NTM 2010) - the least CO2-emission intensive transportation mode, it has an extremely poor overall ecological performance. In particular, the combustion of residual oil and the amount of nitrogen oxide, sulphur oxide and particle emissions are highly problematic and contribute to a large ecological footprint. This in sum makes railway the environmentally most sound transportation mode for long distances.

Nevertheless, the new rail network is not intended to replace the existent transportation mix; it is designed to complement it. From an economic point of view, rail transport represents an intermediate segment that is located between air cargo and container ships. It is at least twice as fast as shipping the goods by sea but, at the same time, it is much more expensive (Arduino 2014). By 2014, approximately 80 per cent of global trade was carried by ship (South China Morning Post 2014).$^{41}$ It is to be expected that this will not change in the foreseeable future. Apart from the cost factor, the railway connections face technical problems like the use of different gauges in various countries. Several essential gauge changes along the route slow down the speed of freight transport and restrain possible time advantages that freight trains could offer in theory. Rail transport is much cheaper than air freight but the railway is nevertheless unable to compete with flight connections in terms of speed. In addition, airlines also count on substantial increases in passenger transport and invest accordingly ( $\mathrm{Li} 2015) .{ }^{42}$

The OBOR initiative is explicitly aimed at boosting the transport capacities of land- and sea-routes as well as strengthening international hub airports. Correspondingly, a considerable expansion in all segments is envisaged, in accordance with the original vision of a Eurasian trade network. This expansion is backed by the Chinese government's policy concerning the 'greening' of freight and logistics. The mid-to-long-term development plan (2014-2020) aims at a number of measures to strengthen 'green' transportation and logistics and to raise efficiency gains. Nevertheless, a change of the modal split is not intended (The State Council $2014 b$ ), thus restricting the possibilities to reduce the overall emissions of the transport sector; the options to improve the environmental balance sheet of the various transportation modes are restricted. 
Pull factors aiming to facilitate the development of technical innovations are in place. The 'Made in China 2025' strategy (Zhang 2015), ${ }^{43}$ which has been unveiled by China's State Council, promotes the development of high-end technology in all transportation modes. This includes sustainability innovations. But - at the same time - the strategy is strongly linked to economic growth targets. Thus, all four motorized transportation modes are among the ten key sectors that are to be supported as part of this plan. Intensified promotion of low-carbon transport modes in order to achieve a more sustainable model split is not part of the plan.

Push factors with regard to the transportation sector are also scarce. As kerosene and marine diesel are not taxed, there are few financial incentives for transportation and logistics enterprises to change their transportation modes, particularly as there is no pressure coming from reduction targets.

\section{Quantitative Optimization as Sustainability Strategy}

Attempts to improve the environmental performance of both the industries discussed above tend to concentrate on efficiency optimization. This is largely reflected in the sustainability strategies formulated by multinational enterprises and trade associations themselves.

As a rule, all multinationals publish their own sustainability strategies. However, although radical technical innovations have been made and can be found in these strategies - like the aforementioned invention of several types of ecological-friendly cement as alternatives to Portland cement (Rousseau n.d.) - innovations are not central to most strategies. Instead, quantitative innovations, like improving efficiency in production and administrative processes to reduce impacts, remain at the core of most sustainability strategies - thus restricting the opportunities for structural change. International frameworks, mostly designed as selfregulatory initiatives, have been established by industry associations such as the International Coalition for Sustainable Aviation (ICSA), the Clean Shipping Coalition (CSC) or the Cement Sustainability Initiative (CSI).

In addition, non-sector-specific international organizations, like the OECD guidelines for Multinational enterprises (OECD 2008), the United Nation's Global Compact (Global Compact 2015), ${ }^{44}$ the Global Reporting Initiative (GRI 2015) ${ }^{45}$ or the World Business Council for Sustainable Development (WBCSD 2012) provide guidelines and monitoring tools in order to assist companies to achieve more sustainable performance 
results. By formulating general principles and providing monitoring systems industry initiatives improve sustainable performance, but they are not suited to the initiation of fundamental transition processes.

\section{The Influence of Multilateral Financing Institutions: The Example of AIIB}

Important additional performance regulations come from the financing institutions. All financing institutions involved in the OBOR initiative provide regulatory frameworks that address environmental goals; the most comprehensive has been formulated by the AIIB (Asian Infrastructure Investment Bank). Its Environmental and Social Framework (AIIB 2016a: 14) requires, inter alia, private and public clients to undertake environmental and social assessments, including evaluations of environmental data and risks as well as prescribing monitoring and reporting measures for ongoing projects to ensure compliance with the framework. These regulations are complemented by an exclusion list, which expressly precludes the financing of socially or environmentally harmful projects (AIIB 2016a: 46-47). On the whole, the formulation of the guidelines nonetheless leaves considerable room for manoeuvre. They allow for mitigating, offsetting and compensating for adverse impacts, and so on. Being firmly committed to the principles of green growth, the regulations aim to deal as effectively as possible with negative effects, without losing the primary focus on economic growth. While supporting environmentally sounder behaviour among clients, and thereby providing comparatively soft regulatory push, the guidelines cannot be expected to encourage the waiving of unsustainable practices on this basis.

Particularly in connection with multinational transport and construction infrastructure providers, the envisaged AIIB Energy Strategy could theoretically be an important instrument as the energy mix promoted in this context could have a substantial and direct impact on the CO2intensity of the project units. But here again, the effectiveness of the guidelines depends on the actual strength of the focus on sustainable energy sources. The preliminary issues note (AIIB 2016b) provides for the support of renewable energy, but does not exclude active support of technically advanced fossil fuel based energy production. Push impacts to adopt major sustainability-relevant innovations are restricted within the broad limits of the issues note, thus limiting the immense potential of the regulating strategy. 


\section{Conclusion}

In sum, economic pressure for European and Chinese multinationals to leave the current path due to slower economic growth in China and a weak economy in the eurozone is apparent as a potential push factor. Investing in 'green economy' strategies as an alternative to business as usual holds forth the promise of economic success. This does not, however, really translate into a need to profoundly change routines or to embark on innovative paths for the industry sectors addressed in this article. One reason is that current stimulus programmes, especially the OBOR initiative, maintain the prospect that a fundamental shift will not be necessary.

Moreover, against the background of enormous demand, particularly as many Asian and European regions are under pressure to catch up economically, the lack of orientation towards sustainable development objectives is unlikely to negatively influence the economic success of the companies involved. The main incentives generated by the OBOR initiative focus on economic growth. Although there are also some environmental goals, they are generally assumed to be compatible with economic growth targets. Without exception, for the industry sectors considered here this results in environmental goals ranking second to efforts to stabilize and promote economic parameters.

Ecological improvements that are triggered by national provisions or self-regulatory initiatives certainly improve environmental performance but they do not bring about structural change. Past experience has clearly shown that quantitative innovations incur a high risk of rebound effects - which are in this case very likely to arise, given the scope of the envisaged project. Multilateral financing institutions generally have great potential to stimulate behaviour changes. But as the example of AIIB shows, these potentials rarely reach fruition; environmental frameworks aiming at innovation push are provided, but they leave much scope for companies to remain on unsustainable paths.

Ultimately, both push and pull factors within the framework of governance arrangements remain weak, as in the preceding discussions of the transport and cement industries. A change of the modal split or a shift towards more environmentally sound building materials are therefore not to be expected on the basis of currently available governance instruments. Instead, institutional regulation and incentive systems support minor 'green' changes but have - on the whole - a rather reinforcing effect on the orientation towards conventional development paths for the multinational enterprises involved in the OBOR project. 
Ulrike Solmecke is a research associate at the Department of International Political Economy of East Asia/Ruhr-University Bochum. Her main research interests include the role of China in global environmental governance processes and social and ecological transformation approaches in East Asia. Email: ulrike. solmecke@rub.de

\section{NOTES}

1 Eyler, Brian 2015a. 'China's new silk roads tie together three continents'. Chinadialogue, 14 April. https://www.chinadialogue.net/article/show/single/en/7849-China-snew-silk-roads-tie-together-3-continents. Accessed 19 November 2015.

2 Leung, Kin Pong 2015. 'One Belt One Road' - Implications for the European Union. European Union Academic Programme Hongkong, 2 June. http:/ / euap.hkbu.edu. hk/main/ one-belt-one-road-implications-for-the-european-union/. Accessed 7 December 2015.

3 Maritime Insight 2015. 'The One Belt, One Road Initiatives'. Maritime Insight, 1. http://www.icms.polyu.edu.hk/research_maritimeInsight/2015-Jun-en/3.pdf. Accessed 19 December 2015.

4 Suárez, Gonzalo 2014. Arranca el viaje en ferrocarril más largo del mundo (Starting the longest train ride in the world). El Mundo, 11 November. http:/ / www.elmundo. es/cronica/2014/11/30/5479b71ce2704e591e8b4577.html. Accessed 5 January 2016.

5 Wangyi 2015. 'Yi dai yi lu guihua dai gongbu 20 sheng zhengfu gongzuo baogao zhondian buju' (One Belt, One Road plan incorporated as a focus in the political planning of 20 provinces). Wangyi (Caijing), 26 February. http://money.163. com/15/0226/14/AJCUOJE400253B0H.html. Accessed 13 December 2015.

6 Zhao, Jing 2015: 'Ma Kai: Yao zhao zhun "Yi dai yi lu" changyi he "Ouzhou touzi jihua" qihe dian' (Ma Kai: It is vital to look for synergies between the "One Belt, One Road" plan and the European Investment Plan"), Shanghai Stock Information - CNStock, 29 September. http:/ / news.cnstock.com/news/sns_bwkx/201509/3579661. htm. Accsessed14 December 2015.

7 Xinhua 2015. 'China, five CEE countries signed memo to promote Belt and Road Initiative' Xinhuanet, 26 November. http://news.xinhuanet.com/english/201511/26/c_134858862.htm. Accessed 5 January

8 Blanco Pitlo, Lucio 2015. 'ASEAN Connectivity and China's "One Belt, One Road"'. The Diplomat, 26 March. http:/ / thediplomat.com/2015/03/asean-connectivity-andchinas-one-belt-one-road/. Accessed 6 January 2016.

9 The agreement has entered into force on 4 November 2016, contingent on its ratification by 55 countries, which produce at least 55 per cent of the worldwide greenhouse gas emissions. The agreement will be open for signature from 22 April 2016 to 21 April 2017 (FCCC/CP/2015/L.9/Rev.1: 2).

10 UNFCCC INDC 2015. Intended Nationally Determined Contributions (INDCs). http:/ / unfccc.int/focus/indc_portal/items/8766.php. Accessed 17 December 2015.

11 Wang, Jingjing 2015b. "'One Belt, One Road" likely to raise China's GDP'. China Daily, 3 March. http://www.chinadaily.com.cn/business/2015-03/25/content_19908124. htm. Accessed 3 November 2015.

12 Multinational enterprises or multinationals are defined here as internationally operat- 
ing companies with a multinational strategic orientation (Gabler Wirtschaftslexikon 2015. 'Multinationale Unternehmung'. http:/ / wirtschaftslexikon.gabler.de/Definition/multinationale-unternehmung.htms. Accessed 3 November 2015).

13 Dai, Emma 2014: "'One Belt, One Road" offers great potential for logistics'. China Daily, 20 November. http:/ / www.chinadaily.com.cn/hkedition/2014-11/20/content_18944968.htm. Accessed 10 December 2015.

14 Shu, Jifu 2016. 'Yi dai yi lu shi kechixu fazhan jiyu haishi dui huanjing de tiaozhan' (Is the One Belt, One Road an opportunity for sustainable development or a challenge for the environment) . Baidu Zhidao, 5 January. http://zhidao.baidu.com/question/1990678099688972027.html. Accessed 6 January 62016.

15 Ni, Dandan 2015. 'Freight trains and cold chains'. Global Times, 5 November. http:/ / file:/ / F:/Artikel/2015/Silk\%20Road \%20and\%20Multinational\%20Enterprises/ Ni\%20Dandan_2015_\%28Global\%20Times\%29\%20Freight\%20trains\%20and \%20c old\%20chains.htm. Accessed 7 December 2015.

16 Ding, Qingfen 2010. 'E-commerce set for rapid growth'. China Daily, 31 August. http://www.chinadaily.com.cn/bizchina/2010-08/31/content_11232419.htm. Accessed 8 December 2015.

17 The State Council 2016. State Council seeks better local governance, assigns e-biz zones, 6 January. http://english.gov.cn/premier/news/2016/01/06/content_ 281475267487435.htm. Accessed 6 January 2016.

18 Chengdu Ribao 2015: 'Ba Chengdu jiancheng ''yi dai yi lu' de zhanlüe zhicheng' (Making Chengdu a strategic pillar of the "One Belt, One Road"), 15 April. http://ktx. tynews.com.cn/c/2015-04/15/content_78478.htm. Accessed 3 January 2015.

19 Wang, Jianing 2015a. 'Chongqing weirao "yi dai yi lu" buju guoji hangxian' (Chongqing plans international route in the context of "One Belt, One Road"). Xinhuanet, 26 November. http://news.xinhuanet.com/fortune/2015-11/26/c_1117266813.htm. Accessed 2 January 2016.

20 Eyler, Brian 2015b. 'Who's afraid of China's One Belt One Road Initiative?'. East by Southeast, 24 April. http:/ / www.eastbysoutheast.com/whos-afraid-of-chinas-onebelt-one-road-initiative/. Accessed 13 December 2015

$21 \mathrm{He}$, Yafei 2015. 'China's overcapacity can spur growth through overseas expansion'. Insight \& Opinion, 8 January. http:/ / www.scmp.com/comment/insight-opinion/ article/1399681/chinas-overcapacity-crisis-can-spur-growth-through-overseas. Accessed 10 December 2015

22 Wei, Zhetan 2015. 'China's One Belt, One Road project could aid recovery in global shipping'. Lloyd's Loading List. http://www.lloydsloadinglist.com/freight-directory/news/China \%E2\%80\%99s-One-Belt-One-Road-project-could-aid-recoveryin-global-shipping/65190.htm. Accessed 3 January 2016.

23 EU 2015. 'Regulation (EU) 2015/1017 of the European Parliament and of the Council of 25 June 2015 on the European Fund for Strategic Investments, the European Investment Advisory Hub and the European Investment Project Portal and amending Regulations (EU) No 1291/2013 and (EU) No 1316/2013 - the European Fund for Strategic Investments'. Official Journal of the European Union, L 169, 1 July. http:/ / eurlex.europa.eu/legal-content/EN/TXT/PDF/?uri=OJ:L:2015:169:FULL\&from=DE. Accessed 18 December 2015.

24 Michael, Martina 2015. 'China-led AIIB will be lean, clean and green'. Business News, 12 April. http://uk.reuters.com/article/2015/04/12/uk-asia-aiibidUKKBN0N302D20150412. Accessed 10 December 2015.

25 The State Council 2014b. Guowuyuan guanyu yinfa wuliuye fazhan: Zhong chang qi guihua tongzhi. (The State Council on the development of the logistics industry: middle and long term plan) The State Council of the People's Republic of China, 
September 12. http://www.gov.cn/zhengce/content/2014-10/04/content_9120. htm. Accessed 3 January 2016.

26 The State Council 2015. Action plan on the Belt and Road Initiative, 30 March. http:/ / english.gov.cn/archive/publications/2015/03/30/content_281475.htm. Accessed 12 December 2015.

27 Xinhua 2014. "'Green Silk Road", new engine for world sustainable development'. Xinhuanet, 13 July. http://www.china.org.cn/business/2014-07/13/content_32935034. htm. Accessed 18 December 2015

28 European Federation for Transport and Environment 2011. Shipping and Climate Change. http://www.transportenvironment.org/wht-we-do/shipping/shippingand-climate-change. Accessed 17 November 2015

29 CSI 2015. Cement industry aspires to reduce CO2 emissions by 20-25\% by 2030. Cement Sustainability Initiative, December 8. http://www.wbcsdcement.org/index.php/ en/news-stories/2015/473-cement-industry-aspires-to-reduce-co2-emissions-by20-25-by-2030. Accessed 2 January 2016

30 The State Council 2014a. Guowuyuan bangong ting guanyu yinfa nengyuan fazhan zhanlüe xingdong jihua (2014-2020 nian) de tongzhi (Energy Development Strategic Action Plan [2014-2020]). http://www.gov.cn/zhengce/content/2014-11/19/content_9222. htm. Accessed 20 December 2015.

31 The State Council 2014c. Guowuyuan yinfa guojiaying dui qihou bianhua guihua (20142020) pifu. (National Climate Change Adaptation Plan [2014-2020]). http:/ /www. gov.cn/xinwen/2014-09/19/content_2753014.htm. Accessed 2 January 2015.

32 This does not only include renewables as sustainable energy resources but nuclear power as well.

33 Xiang, Bo 2014. 'China unveils energy strategy, targets for 2020'. Xinhuanet, 19 November. http://news.xinhuanet.com/english/china/2014-11/19/c_133801014. htm. Accessed 20 December 2015.

34 NDRC 2014. China's Policies and Actions on Climate Change (2014). Beijing: The National Development and Reform Commission. http:/ / en.ccchina.gov.cn/archiver/ccchinaen/UpFile/Files/Default/20141126133727751798.pdf. Accessed 30 November 2015

35 NDRC 2015. China's Policies and Actions on Climate Change (2015). Beijing: The National Development and Reform Commission. http:/ / en.ccchina.gov.cn/archiver/ ccchinaen/UpFile/Files/Default/20151120095849657206.pdf. Accessed 2 January 2016.

36 China Daily 2013. The decision on major issues concerning comprehensively deepening reforms. http://www.china.org.cn/china/third_plenary_session/2013-11/16/content_30620736.htm. Accessed 19 November 2015.

37 McGarrity, John and Beth Walker 2015. 'Chinese-funded energy projects in Pakistan likely to damage environment'. Chinadialogue, 22 April. https://www.chinadialogue. net/article/show/single/en/7861-Chinese-funded-energy-projects-in-Pakistanlikely-to-damage-environment. Accessed 29 November 2015.

38 Rosenthal, Elisabeth 2007: 'Cement industry is at center of climate change debate'. The New York Times, 26 October 26. http:/ / www.nytimes.com/2007/10/26/business/worldbusiness/26cement.html?_r=0. Accessed 25 November 2015.

39 van der Kley, Dirk 2016. 'China shifts polluting cement to Tajikistan'. Chinadialogue, 8 August. https://www.chinadialogue.net/article/show/single/en/9174-Chinashifts-polluting-cement-to-Tajikistan. Accessed 9 September 2016.

40 Rousseau, Marie-Christine, n.d.. 'Neuer Öko-Zement soll CO2-Ausstoß am Bau deutlich senken'. Econitor Magazin. https://www.econitor.de/magazin/lifestyle/ neuer-oeko-zement-soll-co2-ausstoss-am-bau-deutlich-senken_14669.html. Accessed 
December 14, 2015.

41 South China Morning Post 2014. 'First freight train from China arrives in Spain after 13,000 km test run', 10 December. http://www.scmp.com/business/china-business/article/1659300/first-freight-train-china-arrives-spain. Accessed 17 December 2015.

$42 \mathrm{Li}$, Wenfang 2015. "'Belt and Road" to pay off for China Southern'. China Daily, 23 April. http://www.chinadaily.com.cn/business/2015-04/23/content_20515769. htm. Accessed 18 December 2015.

43 Zhang, Minyu 2015. 'Guowuyuan yinfa "Zhongguo zhizao 2025"' (State Council publishes "Made in China 2025" strategy). Xinhuanet, 19 May. http:/ / news.xinhuanet. com/politics/2015-05/19/c_1115331338.htm. Accessed 19 December 2015.

44 Global Compact 2015. The Ten Principles of the UN Global Compact. https://www. unglobalcompact.org/what-is-gc/mission/principles. Accessed 2 January 2016.

45 GRI 2015. G4 Sustainability Reporting Guidelines. https://www.globalreporting. org/STANDARDS/G4/Pages/default.aspx. Accessed 2 January 2016.

\section{REFERENCES}

AIIB 2015. Articles of Agreement. Beijing: Asian Infrastructure Investment Bank, 29 June.

AIIB 2016a. Environmental and Social Framework. Beijing: Asian Infrastructure Investment Bank, February.

AIIB 2016b. AIIB Energy Strategy: Sustainable Energy for Asia: Issues Note for Discussion. Beijing: Asian Infrastructure Investment Bank, October.

Arduino, Asessandro 2014. 'The New Silk Road'. Short Tem Policy Brief 91, May, Europe China Research and Advice Network (ECRAN).

Chen Fenglin 2015. 'Jianshe 21 shiji haishang sichou zhi lu de chubu gouxiang' (A preliminary concept for building the maritime silk road of the $21^{\text {st }}$ century). The Journal of Humanities, 10: 27-35.

David, Martin 2014. 'Exnovation-Governance im Nachhaltigkeitskontext: Annäherung an eine Typologie'. Regierungsforschung.de, 18 November.

EU 2014. EU launches Investment Offensive to boost jobs and growth. Press Release. Strasbourg: European Commission, 26 November.

EU-China 2015. Factsheet on ''EU-China Investment cooperation''. EU-China High Level Economic Dialogue. Beijing, 28 September.

FCCC/CP/2015/L.9/Rev.12015. Adoption of the Paris Agreement. FCCC/CP/2015/L.9/ Rev.1, United Nations Framework Convention on Climate Change/Conference of the Parties (COP 21), 12 December 2015.

Fung Business 2013. Logistics Industry in China. Hong Kong, New York and London: Fung Business Intelligence Centre.

Hornby, Lucy 2015. 'China's "One Belt One Road" plan greeted with caution', Financial Times, 20 November 2015.

IEA 2009. Transport, Energy and $\mathrm{CO}^{2}$. International Energy Agency. Paris

Lehmann-Waffenschmidt, Markus and Markus Reichel 2000: ,Kontingenz und Lock-in als handlungsbeeinflussende Faktoren im Kontext der Unternehmenspolitik' (Contingency and lock-in as action-influencing factors in the context of corporate policy). In T. Beschorner et al. (eds.) Evolutorische Ökonomik und Theorie der Unternehmung (Evolutionary economics and business theory). Marburg: Metropolis: 337-396.

Luderer, Gunnar et al. 2013. 'Economic mitigation challenges: how further delay closes the door for achieving climate targets'. Environmental Research Letters, 8: 1-8. 
NDRC et al. 2015. Vision and Actions on Jointly Building Silk Road Economic Belt and 21Centruy Maritime Silk Road. National Development and Reform Commission, Ministry of Foreign Affairs, Ministry of Commerce of the People's Republic of China, State Council (authorization), 3 March.

Nelson, Richard R. and Sidney G. Winter 1982. An Evolutionary Theory of Economic Change. Cambride (Mass.): Harvard University Press.

NTM 2010. Environmental Data for International Cargo Transport. Stockholm: Nätverket för Transporter och Miljön.

OECD 2008. OECD Guidelines for Multinational Enterprises. Paris: OECD Publishing.

Perilli, David 2015. '2015 in cement: BRICing it - growth stalls in Brazil, Russia, India and China', Global Cement, 16 December.

Rockström, Johan et al. 2009. 'Planetary Boundaries: Exploring the safe operating space for humanity'. Ecology and Society 14 (2).

Rogers, Everett 2003: Diffusion of Innovations. $5^{\text {th }}$ ed. London, New York, Toronto, Sydney: Free Press.

Solmecke, Ulrike 2014. Starke Nachhaltigkeit im interkulturellen Kontext: Theoretische Überlegungen und praktische Implikationen am Beispiel des Tourismus in der VR China (Strong sustainability in an intercultural context: Theoretical considerations and practical implications - the case of tourism in China). Marburg: Metropolis-Verlag.

Wang, Shuang 2014. 'Xi Jinping ti zhanlüe gouxiang: "Yi dai yi lu"zhu meng kongjian"' (Xi Jinping on the idea of the strategy: "One Belt One Road" opens up space to realize the dream). Zhongguo Jingji Wang, 11 August.

WBCSD 2012. Guidelines for Emissions Monitoring and Reporting in the Cement Industry, version 2.0, Cement Sustainability Initiative.

WEC 2011. Global Transport Scenarios 2050. London: World Energy Council.

Zhang, Xiliang et al. 2014. Carbon emissions in China: How far can new efforts bend the curve? Report 267, Cambridge (Mass.): Massachusetts Institute of Technology.

Zhao, Mingliang and Yang Huixin 2015. "'Yi dai yi lu" zhanlüe xia Zhongguo gangtie ye guocheng channeng huajie: Maoyi jichu, touzi jihui yu shixian jizhi' (Resolving the overcapacity in iron and steel industry of China under the strategy of "One Belt, One Road": Basis for trade, investment opportunity and implementation mechanism). Journal of East China Normal University, Humanities and Social Sciences, 4: 84-92. 